\title{
The Influence of Euphorbia Milii Flower Extract in the Activity of Th17 through IL-17 Secretion in Mycobacterium tuberculosis Infected Mice
}

\author{
Ni Made Linawati ${ }^{1}$, Dewa Made Sukrama², Made Mertaniasih ${ }^{3}$ \\ ${ }^{1}$ Department of Histology, Medical Faculty Udayana University Denpasar-Bali. Indonesia (0361) 222510 \\ ${ }^{2}$ Department of Microbiology, Medical Faculty Udayana University Denpasar-Bali. Indonesia (0361) 222510 \\ ${ }^{3}$ Department of Microbiology Medical, Faculty of Airlangga University
}

\begin{abstract}
The present study was conducted to study Euphorbiamilii flowerextract (EM) in increasingthe activity ofTh17 cellsthroughIL-17 secretion. Thiswas an experimental study with Post TestOnly ControlGroupdesign. 24 BalbC, male, were divided in to 6 groups of treatment whichwere observedat firstandthird week. GroupKland K2arenegativecontrols; PlandP3weregivenOAT and M.tbinfected; while theP2andP4were infected M.tb, givenOATandEM. Terminations of K1, P1andP2were inthe firstweek, while K2, P3andP4 were terminated inthe thirdweek. Pulmonaryorgans were removed for examinationofIL-17 by ELISA. The result showed mean of level ofIL-17 inK1, P1, P2, K2, P3andP4respectivelyis81.18; 90.00; 88.65; 87.53; 75.45and87.53 pg/ml. EMextractsincreased the concentration ofIL-17 in the third weekhigher than thegroup thatdid not receivethe extractbut the difference wasnot significantly. It happenedprobablybecausea lot offactors thataffect the stability ofIL-17, thus affecting theoutcome. It is necessary forfurther research onthe mRNAexpression of $I L-17$, so thatthe influence factorscan be minimized.
\end{abstract}

Keywords: Euphorbia milii, Mycobacterium tuberculosis, Th17, IL-17

\section{Introduction}

Mycobacterium tuberculosis has caused 1.4 million deaths each year in which Indonesia now ranked fifth among countries with the highest tuberculosis burden in the world ${ }^{1}$. Transmission occurs after inhaling droplets containing Mycobacterium tuberculosis and are deposited on the distal alveoli. In which alveolar macrophages and dendritic cells that fagocyt mycobacteria, forming fusion phagolysosome though in a state of optimal activation of macrophages, NK, dendritic then Mycobacterium tuberculosis often unable to cope with preventing fusion phagolysosome ${ }^{2}$. Research over the years acquired the role of $\mathrm{Th} 1 \mathrm{CD}^{+}$through the secretion of IFN- $\gamma$ were able to increase the activation of macrophages to kill intracellular mycobacteria. But the last few years found a new subset of CD4 + Th cells that Th17 are not related to the secretion of IFN- $\gamma$. Th17 cells that secrete IL-17 proved to have a protective role of Th1 and Th2 subsets currently unable to fight extracellular bacteria. Th17 role through the secretion of IL-17 in the pathogenesis of tuberculosis shows protective capability against Mycobacterium tuberculosis infection equaled IFN- $\gamma$ but without effect induced damage to lung tissue $\mathrm{e}^{3,4}$. Also found a decrease in the population of Th17 cells and the secretion of IL-17 in patients with active pulmonary tuberculosis ${ }^{5}$. This shows that the optimal activity of Th17 cells through the secretion of IL-17 is important in the fight against Mycobacterium tuberculosis infection to prevent active disease manifestations. So it is necessary to found drugs from natural materials which have the ability to modulate the optimal activation ofTh17 through the secretion of IL17. This study is a continuation of research in the first year that showed EM was able to increase NK cell activity in mice infected with Mycobacterium tubercullosis through NKp46 expression $^{6}$. In the second year of this study aims to prove that EM able to increase the expression of Th17 through the IL-17 in mice infected with Mycobacterium tuberculosis.

\section{Material and Methods}

This research is an experimental post-test only control group design. A total of 24 BalbC mice, 8 weeks old are placed randomly in 6 cages, each cage containing 4 mice. They are adapted for 2 weeks. The first day after the adaptation, the group $\mathrm{K} 1$ and $\mathrm{K} 2$ is given only sterile distilled water; group P1, P2, P3 and P4 M.tb infection strain H37Rv given intranasally by $60 \mathrm{~mL}$ with a concentration of germs $10^{5}$. Then next day, the group $\mathrm{K} 1$ and $\mathrm{K} 2$ as control are given only sterile distilled water of $1 \mathrm{ml} /$ day, the group P1 and P3 are given standard medication INH $0.5 \mathrm{mg} / 20$ grbw; P2 and P4 group given standard drugs INH $0.5 \mathrm{mg} / 20$ grbw and EEM dose of $10 \mathrm{mg} / 20 \mathrm{grbw}$. Giving done every day for 21 days. On day 8 carried the termination of each 4 mice in group $\mathrm{K} 1, \mathrm{P} 1$ and $\mathrm{P} 2$, while on day 21 the termination of 4 mice performed again in the K2 group, P3, and P3, take pulmonary organs and prepared asstandard procedure for measuring the secretion of IL -17 by ELISA (R \& D Systems).

\section{Result}

The Secretion of IL-17 in groups of study

The concentration of IL - 17 from lung samples obtained by the formula slot -intercept of the standard OD values and samples. Average concentration of IL - 17 in group K1, P1, P2, K2, P3 and P4 are respectively $81.18 ; 90.00 ; 88.65$; $87.53 ; 75.45$ and $87.53 \mathrm{pg} / \mathrm{ml}$. Data analysis indicates that the data is normally distributed, One Way Anova resultthere was no significant difference between groups in IL- 17 secretion $(p=0134)$. However, if seen IL-17 level curve in 


\section{International Journal of Science and Research (IJSR) \\ ISSN (Online): 2319-7064}

Index Copernicus Value (2013): 6.14 | Impact Factor (2014): 5.611

all groups of treatment (Figure 1) appears there were differences secretion of IL- 17 in the research groups .

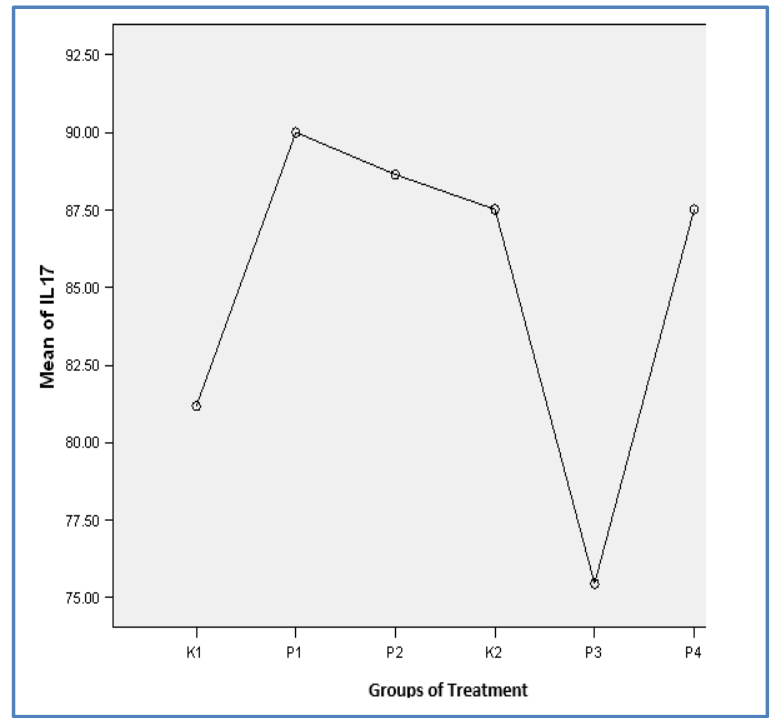

Figure 1: Interleukin 17 level (pg/ml) curve in all groups of treatment

\section{Discussion}

In the first week the concentration of IL-17 highest in P1 while the third week the concentration of IL-17 in group P4 (OAT and EM) equaled the control group. The test results One Way Anova indicating no significant difference between groups. This due to cytokines such as IL-17 stability is influenced by various factors that require peak right time for measuring the secretions. As also described by korn 2009 that the differentiation of T cells into Th17 cells is influenced by many factors and chemokine such as differentiation factors (TGF- $\beta$, IL-6, IL-21), growth factors and stabilization (IL-23), as well as transcription factors ( STAT3, ROR $\gamma \mathrm{t}$, and $\operatorname{ROR} \alpha)^{7}$. The curve showed the secretion of IL-17 in third week on P4 group equaled with group of control (K2) and also higher than P3. This shows that the extract was given for 3 weeks in grup of intervened M.tb and granted OAT able to increase IL-17 equaled with the normal group. While EM intervention provided only within 1 week (P2) was not able to increase the secretion of IL-17. It ischaracteristics ofimmunostimulatoryfromnatural materials in which to work optimally it requires a fairly large doses and long enough time, but the side effects are smaller than a synthetic immunostimulatory ${ }^{8}$.

\section{Conclusion}

From the above results it can be concluded that The ethanol extract of Euphorbia milii( EM ) increase the secretion of IL - 17 in the third week, but the increase was not shown significantly.

\section{References}

[1] Anonim 1. Kenmenkes RI. 2011. Strategi Nasional Pengendalian TB di Indonesia 2010-2014. P. 1-80.

[2] Philips JA, Ernst JD. 2012 Tuberculosis pathogenesis and immunity. Annu Rev Pathol 7: 353-84
[3] Roldan, C, P., Barba, J., Valdes, M, A, F. Th17: A New Player to be Considered in Tuberculosis Studies. J Bacteriol Parasitol. 3(-) : 9 http://dx.doi.org/10.4172/2155-9597.1000e115

[4] Li, Q., Li, J., Tian, J., Zhu, B., Zhang,Y. 2012. IL-17 and IFN- $\gamma$ production in peripheralblood following BCG vaccination and Mycobacterium tuberculosis infection in human. European Review for Medical and Pharmacological Sciences. 16 (-) : 2029-36

[5] Chen, X., Zhang, M., Liao, M., Graner, M, W., Wu, C. 2010. Reduced Th17 Response in Patients with Tuberculosis Correlates with IL-6R Expression on CD4 ${ }^{+}$ $\mathrm{T}$ Cells. American Journal of Respiratory and Critical Care Medicine. 181 (7): 734-42.

[6] Linawati, N, M., et al. 2014. The Optimal dose of Euphorbia milii extracts in NKp46 expression against mice infected with Mycobacterium tuberculosis. Journal of US-China Medical Science. 2014. 11(2): 68-73.

[7] Korn, T., Bettelli, E., Oukka, M., Kuchroo, V, K. 2009. IL-17 and Th17 cells. Annu Rev immunol. 27 (-): $485-$ 517

[8] Tamioka H. 2004. Adjunctive Immunotherapy of Mycobacterial Infections. Current Pharmaceutical Design 10: 3297-3312. 